\title{
MICROWAVE PYROLYSIS OF BIOMASS IN A ROTATORY KILN REACTOR: DEEP CHARACTERIZATION AND COMPARATIVE ANALYSIS OF PYROLYTIC LIQUIDS PRODUCTS
}

\author{
Lilivet UBIERA, Isabelle POLAERT, Lokmane ABDELOUAHED, Bechara TAOUK
}

\author{
Normandie University, INSA Rouen, LSPC, EA 4704 - INSA Rouen, Avenue de l'Université \\ - Saint-Étienne-du-Rouvray cedex 76801 France \\ e-mail : isabelle.polaert@insa-rouen.fr
}

Keywords: Microwave pyrolysis, Rotatory Kiln Reactor, Flax Shives, Green fuels

\section{Introduction}

Process intensification by maximizing the production efficiency and minimizing the hazardous effects on the environment and human health is one of the main objectives nowadays, in which the biggest question is how to create a new sustainable relationship between a growing industry and our planet. In this context, both, the industry and the scientific community are increasingly concerned about the environmental deterioration and the economic risks associated with the increasing demand and dependency on fossil fuels. The pursuit of sustainable relationship between the production and consumption of energy has accelerated the research into new fuels alternatives, and mainly focused on new technologies for biomass based fuels. The potential of lignocellulosic biomass for power generation has been studied several times and it is considered as a promising renewable energy source. [8] In France, for example, around 200,000 tons of flax shives are generated annually by the flax industry, being $80 \%$ of the world's production of scutched flax fibers originated in Europe, being France, the world leader [4]. The potential of this biomass to be integrated as a power source has not been completely explored. Some of the investigations done about the exploitation of flax shives as raw material for the biofuel production by thermochemical conversion has been done in our laboratory but only for conventional heating method and to the best of our knowledge, this is the first time that the flax shives pyrolysis has been evaluated under microwave heating conditions [1][6].

Microwaves are electromagnetic radiations placed between the radio and infrared waves in the electromagnetic spectrum. The frequency of the microwaves is in a range between $300 \mathrm{MHz}$ and $300 \mathrm{GHz}$ but for industrial application the most commonly used are $2.45 \mathrm{GHz}$ and $915 \mathrm{MHz}$. The use of microwaves as a heating method for pyrolysis process has been long recognized to provide better quality bio-products in shorter reaction time due to the direct sample heating and the particular heating profile resulting from the interaction of biomass with the electric field component of an electromagnetic wave. [7][1][8]

Also, it has been reported by [2] that reactor design may have a great influence on the pyrolysis product yields. The rotatory kiln reactor provides a homogeneous heating profile inside the reactor which is desired for a fast microwave pyrolysis to avoid hot-spots. During the course of this research, flax shives were pyrolysed using a rotatory kiln reactor inside a microwave single mode cavity using a range of power between 200 and 300 watts, to reach a temperature range between $450{ }^{\circ} \mathrm{C}$ and $700^{\circ} \mathrm{C}$. The liquid bio-oil samples recovered in each case were analyzed though gas chromatography-mass spectrometry (GC-MS) and gas chromatography-flame ionization detection (GC-FID) to identify and quantify the different 
molecules produced. The aim of this work is to investigate the upgrading of flax shives via microwave pyrolysis and shed some light on its pyrolytic behaviour.

\section{Experimental section}

\section{Materials and Elemental Analysis}

The samples for this study were Flax Shives, a lignocellulosic biomass provided by "La cooperative Terre de Lin'. The samples were ground and sieved in our laboratory. The average particle size ranged between 300 and $400 \mu \mathrm{m}$.

The total $\mathrm{C}, \mathrm{H}$, and $\mathrm{N}$ were measured on sub-samples using a $\mathrm{CHN}$ elemental analyzer Flash 2000 (Thermofisher Scientific). Also a proximate analysis was done based on TGC experiments. Both results were published by part of our research group in the publication [6]

Table 1. Elemental Analysis [6]

\begin{tabular}{|c|c|c|c|c|}
\hline \multicolumn{5}{|c|}{ Elemental Analysis (\% w:w) } \\
\hline \multirow{2}{*}{ Flax Shives } & Carbon & Hydrogen & Nitrogen & Oxygen \\
\cline { 2 - 5 } & 45.70 & 5.77 & 0.41 & 48.12 \\
\hline
\end{tabular}

The analysis of the percentage of lignocellulosic biomass pseudo-components has been done based on TGA experiments.

Table 2. Flax shives composition based on TGA experiments [6]

\begin{tabular}{|c|c|c|c|c|}
\hline \multicolumn{5}{|c|}{ Proximate Analysis (\% w:w) } \\
\hline Flax Shives & Humidity & Volatile Matter & Fixed Carbon & Ash \\
\cline { 2 - 5 } & 8.28 & 69.22 & 19.97 & 2.53 \\
\hline
\end{tabular}

\section{Experimental set up}

This study used a single-mode microwave cavity. The microwaves were generated by a SAIREM magnetron at a frequency of $2.45 \mathrm{GHz}$ and a power between 0 and $2000 \mathrm{~W}$. The incident and reflected microwaves powers were recorded using two bolometers and the absorbed power was deduced from the two first measured powers. A system of three manual sliding short-circuit was used to maximize the wave-matter interaction and to maintain a range of reflective wave between 5 and $15 \%$, taking advantage of a minimum of 85 percent of the applied power.

The pyrolysis process was conducted in a rotatory kiln glass reactor, set to rotate at $65 \mathrm{rpm}$ and purged with a $600 \mathrm{~mL} / \mathrm{min}$ of nitrogen to maintain the anoxic conditions. The temperature in the reactor vessel, a glass cylinder of $17 \mathrm{~cm}$ of length and $3 \mathrm{~cm}$ of internal diameter, was measured at the end of the experiment using a thermocouple type $\mathrm{K}$ sensor. This thermocouple was introduced inside the reactor when the microwave heating system was just turned off and placed in the bottom of the glass reactor to measure the final temperature achieved and the cooling ramp. The temperature at the surface of the reactor was measured during the reaction time when the microwaves were "on" using an optical fiber to avoid interference with the electromagnetic field in the waveguide.

After purging the system, the power supply was turned on and switched to the desired microwave power level for 6 minutes. The non-condensable gases were recovered in a sampling bag to be later analysed. The cold bath and the refrigerant were both kept at a constant temperature of $-14{ }^{\circ} \mathrm{C}$. At the end of each experiment, all the reactor parts were 
weighted and the char and oil weights were experimentally deduced. The non-condensable gas weight was estimated thanks to a method using a standard gas phase GC analysis.

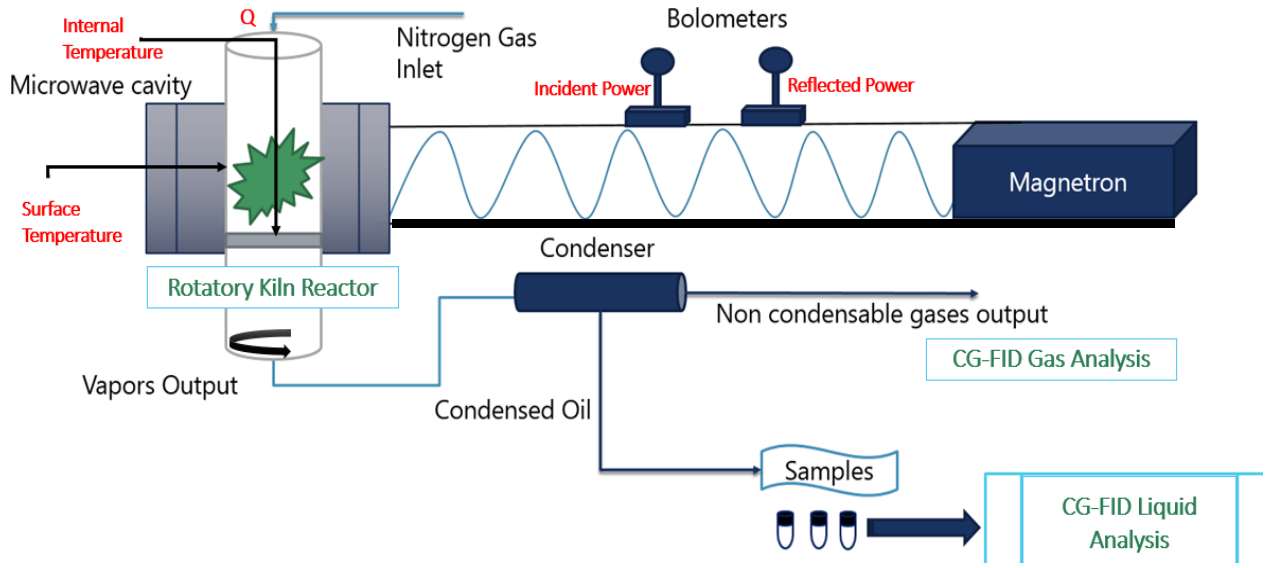

Fig. 1. Experimental Set-up

\section{Analytical procedure of the bio-oil}

The analysis of the recovered bio-oil was performed using a gas chromatograph-mass spectrometer instrument GC-MS (Varian 3900-Saturn 2100T). The column was a VF-1701 $\mathrm{ms}$ (Agilent) (60m x $0.25 \mathrm{~mm} \times 0.25 \mu \mathrm{m}$ film thickness).. The oven was held at $45{ }^{\circ} \mathrm{C}$ for 4 min then heated to $280{ }^{\circ} \mathrm{C}$ with a heating rate of $4{ }^{\circ} \mathrm{C} / \mathrm{min}$ and held for $20 \mathrm{~min}$. The carrier gas was helium with a constant flow of $1 \mathrm{ml} / \mathrm{min}$.

$1 \mu \mathrm{L}$ of the bio-oil sample diluted in pure acetone was directly injected into the heated split injector (split ratio 30:1) at $250 \mathrm{C}$. The detection was performed in a full scan mode and the components were identified with a Varian Work Station and NIST 2002 software by comparing the mass spectrum with the NIST's library.

Kovats's retention indices of the identified components were then calculated and compared to the reference value for the conformation of their identity.

After identifying the components of the bio-oil samples, a flame ionization detector (FID), GC-FID Scion 456-GC Bruker instrument was used to quantify the components. The column and temperature program used were the same as the ones used for the GC-MS analysis. The detected compounds were grouped into families of the same functional group and then one representative component in its pure form was taken to make calibration curve for the corresponding family. Five points straight line calibration curves were established for these pure representative compounds, using dodecane as internal standard.

\section{Results and discussion}

\section{Surface vs internal temperature measurement}

When using microwave processes, one of the key points is the temperature evaluation. Both surface temperature (TS) and internal temperature (Tint) were measured during experiments of biomass microwave heating. An optical fiber was used to measure the reactor surface temperature during the experiment and when the optical fiber achieved a temperature equal to $150{ }^{\circ} \mathrm{C}$, the microwave generation was turned off and then a thermocouple was inserted 
until the bottom of the reactor to measure the internal temperature. This procedure was repeated four times in order to check the stability of temperature.

The behaviour observed is presented in the figure 2. It was observed that for the same absorbed power $\left(\mathrm{P}_{\mathrm{abs}}\right)$, the temperature behaviour was similar and stable. It was also noticed that the difference of internal and surface temperature was more than the double for each measurement. When the outer surface temperature of the reactor reaches $150^{\circ} \mathrm{C}$, more than $300^{\circ} \mathrm{C}$ is reached inside the biomass and the steady state inside the reactor is reached faster than outside.

For a reactor of $3 \mathrm{~cm}$ internal diameter, several experiments were done using $4.5 \mathrm{~g}$ of biomass and several incident powers from 100 to $400 \mathrm{~W}$. For each run, the observed temperature inside the reactor, at the heart of the biomass was at least the double of the one at the outer surface of the reactor.

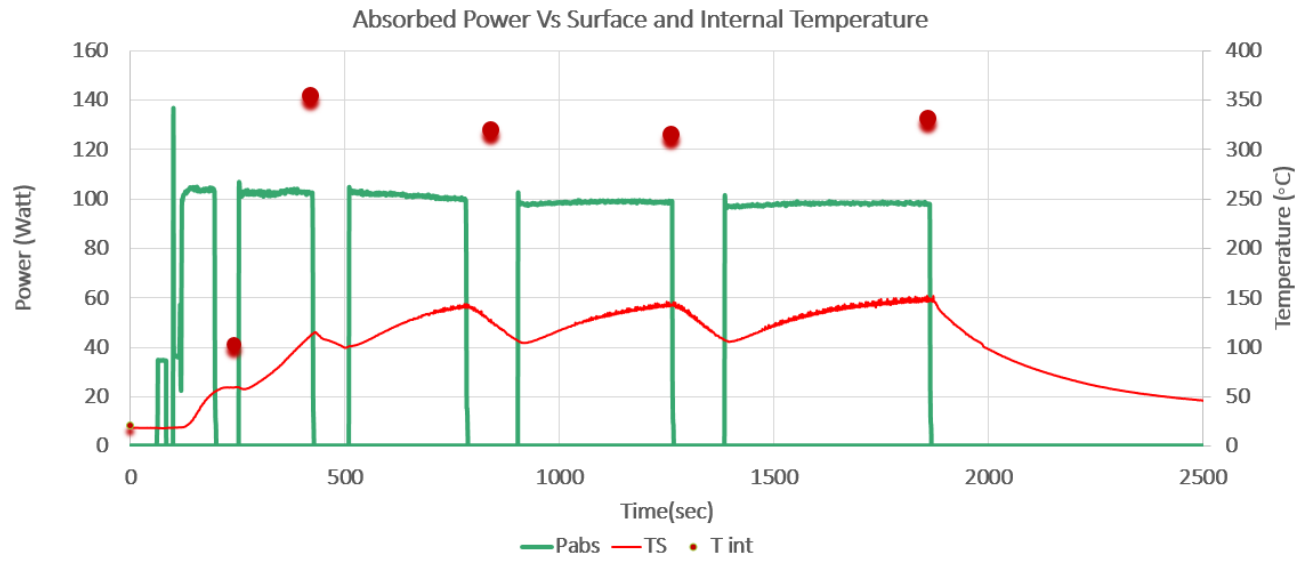

Fig. 2. Absorbed power, surface and internal temperatures during biomass microwave heating: mbiomass $_{\text {b }}=9 \mathrm{~g}$

\section{Microwave power absorption during biomass pyrolysis}

The behaviour of the absorbed, incident and reflected powers measured by bolometers was observed. The performance of the incident and reflected power mirrored the different biomass decomposition phases. For example, figure 3. shows common profiles of incident, reflected and absorbed powers during a pyrolysis experiment. The first zone inside the black square corresponds to the biomass drying period. The second zone in which both incident and reflected power are instable corresponds to the active pyrolysis zone. Inside the active pyrolysis zone, there is phenomena of devolatilization of cellulose and hemicellulose and also a significant mass loss. During this period, the sliding short circuit system is manually adjusted to maximise the absorbed power. At the end of the experiment, a new stable phase begins that can be also called the passive phase which is characterized by the slow degradation of lignin and a weak weight loss. This mechanism of three phases pyrolysis division was also observed by [1] in TGA experiments study for flax shives. 


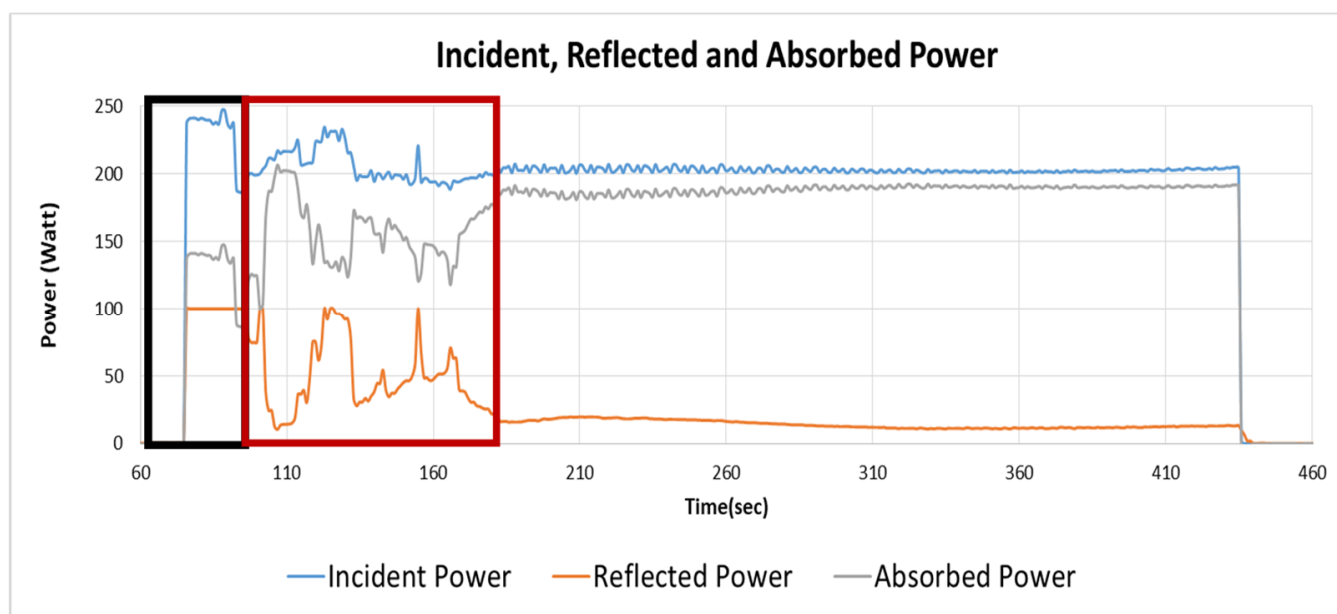

Fig. 3. Incident, reflected and absorbed power during a microwave pyrolysis process

\section{Microwave pyrolysis process results}

Several experiments were carried out with $4.5,6.75$ or $9 \mathrm{~g}$ of biomass. For each mass of biomass, the incident power was varied between 200 and $300 \mathrm{~W}$ for an average absorbed power between 160 and 220 watts respectively. The nitrogen gas flowrate was varied from 300 to $600 \mathrm{ml} / \mathrm{min}$.

Before evaluating the effect of the operational parameters, the repeatability of the microwave pyrolysis process was tested in terms of microwave absorbed power, global energy transferred and maximum temperature reached. First, 4.5 grams of biomass were treated under the same input power $(200 \mathrm{~W})$, vapors residence time and irradiation time $(7 \mathrm{~min})$. The results are presented in the table 3 .

Table 3. Repeatability of experiments

\begin{tabular}{|c|c|c|c|c|c|}
\hline Number & $\begin{array}{l}\text { Mass of } \\
\text { biomass (g) }\end{array}$ & $\begin{array}{l}\text { Average } \\
\text { absorbed } \\
\text { power }(\mathbf{W})\end{array}$ & $\begin{array}{lr}\begin{array}{l}\text { Total } \\
\text { energy }\end{array} & \text { effective } \\
\text { applied }\end{array}$ & $\begin{array}{l}\text { Maximum } \\
\text { temperature } \\
\left({ }^{\circ} \mathrm{C}\right)\end{array}$ & $\begin{array}{l}\text { Vapors } \\
\text { residence } \\
\text { time (s) }\end{array}$ \\
\hline 1 & 4.5 & 162 & 53 & 627 & 1.4 \\
\hline 2 & 4.5 & 158 & 56 & 682 & 1.4 \\
\hline 3 & 4.5 & 164 & 60 & 710 & 1.4 \\
\hline
\end{tabular}

The irradiation method was also evaluated. Different experiments were carried using continuous irradiation mode and compared with discontinuous modes. The results are presented in the table 4 . 
Table 4. Evaluation of microwave irradiation mode

\begin{tabular}{|l|l|l|l|l|l|l|l|}
\hline Number & $\begin{array}{l}\text { Mass of } \\
\text { biomass } \\
\text { (g) }\end{array}$ & $\begin{array}{l}\text { Microwave } \\
\text { irradiation } \\
\text { mode }\end{array}$ & $\begin{array}{l}\text { Irradi } \\
\text { ation } \\
\text { time } \\
\text { (minut } \\
\text { es) }\end{array}$ & $\begin{array}{l}\text { Average } \\
\text { absorbed } \\
\text { power } \\
\text { (W) }\end{array}$ & $\begin{array}{l}\text { Total } \\
\text { effective } \\
\text { energy } \\
\text { applied } \\
\text { (kJ) }\end{array}$ & $\begin{array}{l}\text { Maximum } \\
\text { tempera- } \\
\text { ture } \\
\text { ('C) }\end{array}$ & $\begin{array}{l}\text { Vapors } \\
\text { residenc } \\
\text { e } \\
\text { time } \\
\text { (s) }\end{array}$ \\
\hline 4 & 4.5 & $\begin{array}{l}\text { Continuous } \\
7 \text { min on 240W }\end{array}$ & 7 & 201 & 86 & 568 & 1.6 \\
\hline 5 & 4.5 & $\begin{array}{l}\text { Discontinuous } \\
4 \text { min on 240W } \\
1 \text { min off }\end{array}$ & 7 & 198 & 67 & 640 & 1.3 \\
\hline 3 min on 240W & & & & & & \\
\hline 6 & 4.5 & $\begin{array}{l}\text { Discontinuous } \\
4 \text { min on 200W } \\
1 \text { min off } \\
2 \text { min on 200W }\end{array}$ & 6 & 180 & 58 & 586 & 1.6 \\
\hline
\end{tabular}

In table 3, although incident power has been reproduced, the average absorbed power varies from one experiment to another. It depends on the lapse of every biomass pyrolysis phase (active or passive) during the reaction period, and the tuning effectiveness. Therefore, using the total effective energy (E) defined in equation (1) is more convenient in order to make the comparisons between experiments. $t_{0}$ is the initial irradiation time and $t_{f}$ is the time for which the microwaves are turned off.

$$
E=\int_{t 0}^{t f} P_{\text {absorbed }} d t \quad \text { Equation [1] }
$$

In table 3, this energy is correlated positively with the maximal temperature achieved by the system. In table 4, for the same average absorbed power, an important gap in the effective energy applied is noticed between a continuous and a discontinuous mode. It was shown that for the same time of irradiation, the discontinuous mode promotes a higher temperature with a lower energy, because pyrolysis takes advantage of heat accumulation in the reactor walls.

\section{Microwave pyrolysis products distribution}

For the experiments of the table 4, the products distribution is reported in table 5 and results obtained with an initial mass of 9 grams of biomass are added. The higher the applied energy is, the higher the bio-oil production is and the lowest the char production is. 
Table 5. Microwave pyrolysis products distribution using 4.5 grams or 9 grams of biomass

\begin{tabular}{|c|c|c|c|c|c|c|c|c|c|c|c|}
\hline $\begin{array}{l}\text { Mass of } \\
\text { biomass } \\
\text { (g) }\end{array}$ & $\begin{array}{c}\text { Average } \\
\text { absorbe } \\
\text { d power } \\
\text { (W) }\end{array}$ & $\begin{array}{c}\text { Energy } \\
\text { applied } \\
\text { E (kJ) }\end{array}$ & $\begin{array}{c}\text { Max } \\
\text { temperatu } \\
\text { re } \\
\left({ }^{\circ} \mathrm{C}\right)\end{array}$ & $\begin{array}{l}\text { Vapors } \\
\text { residence } \\
\text { time } \\
\text { (s) }\end{array}$ & $\begin{array}{l}\text { Oil } \\
\text { (g) }\end{array}$ & $\begin{array}{c}\text { Char } \\
\text { (g) }\end{array}$ & $\begin{array}{c}\text { Gas } \\
\text { (g) }\end{array}$ & $\begin{array}{c}\text { Oil } \\
\%\end{array}$ & $\begin{array}{l}\text { Ch } \\
\text { ar } \\
\%\end{array}$ & $\begin{array}{c}\text { Ga } \\
\text { s } \\
\%\end{array}$ & $\begin{array}{c}\text { Total } \\
\text { Product } \\
\text { recovere } \\
\text { d } \\
\%\end{array}$ \\
\hline 4,5 & 201 & 86 & 568 & 1.6 & 2.25 & 0.852 & 0.937 & 50 & 19 & 21 & 90 \\
\hline 4.5 & 198 & 67 & 640 & 1.3 & 2.14 & 0.61 & 0.771 & 48 & $14^{*}$ & 17 & 79 \\
\hline 4.5 & 180 & 58 & 586 & 1.6 & 2.017 & 1.08 & 0.727 & 46 & 24 & 17 & 87 \\
\hline 9 & 222 & 94 & 678 & 6 & 4.32 & 1.89 & - & 48 & 21 & -** & - \\
\hline 9 & 186 & 70 & 600 & 6 & 3.7 & 2.7 & - & 41 & 23 & $-* *$ & - \\
\hline 9 & 156 & 57 & 457 & 6 & 2.7 & 3.06 & - & 30 & 34 & $-* *$ & - \\
\hline
\end{tabular}

*Mass of char was partially recovered. **Mass of gas not available.

The effect of the initial mass of biomass put inside the reactor was evaluated. 9, 6.75 and 4.5 grams were treated during $6 \mathrm{~min}, 200 \mathrm{~W}$ of incident power and nitrogen flowrate of 600 $\mathrm{ml} / \mathrm{min}$. For a similar range of energy absorbed, the initial mass has a strong influence on the maximum temperature achieved and products distribution (see table 6). High loads lead to higher temperature because thermal losses are less and it has a negative influence on the bio-oil production. Gasification is clearly favoured at high temperature at the expense of oil production.

Table 6. Microwave pyrolysis products distribution: effect of the biomass loading

\begin{tabular}{|c|c|c|c|c|c|c|c|c|c|c|c|}
\hline $\begin{array}{c}\text { Mass of } \\
\text { biomass } \\
(\mathbf{g})\end{array}$ & $\begin{array}{c}\text { Average } \\
\text { absorbed } \\
\text { power } \\
(\mathbf{W})\end{array}$ & $\begin{array}{c}\text { Energy } \\
\text { applied } \\
\mathbf{E}(\mathbf{k J})\end{array}$ & $\begin{array}{c}\text { Maximum } \\
\text { temperature } \\
\left({ }^{\circ} \mathbf{C}\right)\end{array}$ & $\begin{array}{c}\text { Vapors } \\
\text { residence } \\
\text { Time } \\
(\mathbf{s})\end{array}$ & $\begin{array}{c}\text { Oil } \\
\mathbf{( g )}\end{array}$ & $\begin{array}{c}\text { Char } \\
(\mathbf{g})\end{array}$ & $\begin{array}{c}\text { Gas } \\
\mathbf{( g )}\end{array}$ & $\begin{array}{c}\text { Oil } \\
\mathbf{\%}\end{array}$ & $\begin{array}{c}\text { Char } \\
\mathbf{\%}\end{array}$ & $\begin{array}{c}\text { Gas } \\
\mathbf{\%}\end{array}$ & $\begin{array}{c}\text { Total } \\
\text { product } \\
\text { recovered } \\
\mathbf{\%}\end{array}$ \\
\hline $\mathbf{4 . 5}$ & 159 & 60 & 710 & 1.3 & 2.4 & 0.85 & 0.91 & 52 & 19 & 20 & 91 \\
\hline $\mathbf{6 . 7 5}$ & 164 & 63 & 794 & 2.1 & 2.9 & 1.4 & 1.1 & 43 & 21 & 17 & 81 \\
\hline $\mathbf{9}$ & 177 & 64 & 805 & 2.6 & 2.8 & 1.8 & 2.1 & 31 & 20 & 24 & 75 \\
\hline
\end{tabular}

\section{Microwave pyrolysis bio-oil characterization}

The liquid bio-oil samples recovered in each case were analyzed to identify and quantify the different molecules produced. As an example, results are reported in table 7 for the three experiments of table 4. Molecules were grouped into 11 families, as shown in figure 4. Figure A and B correspond respectively to the results obtained by the GC-FID analysis for the first and the second line of table 7. Results for the third line are similar to the last ones. In general, the bio-oil samples are composed of about 40-50 wt. \% of carboxylic acids, 15 20 wt. $\%$ of phenols, $12-14$ wt. \% of ketones and 8-10 wt. \% of esters majorly. Carboxylic acids are the dominating chemical group present, followed by phenols. 


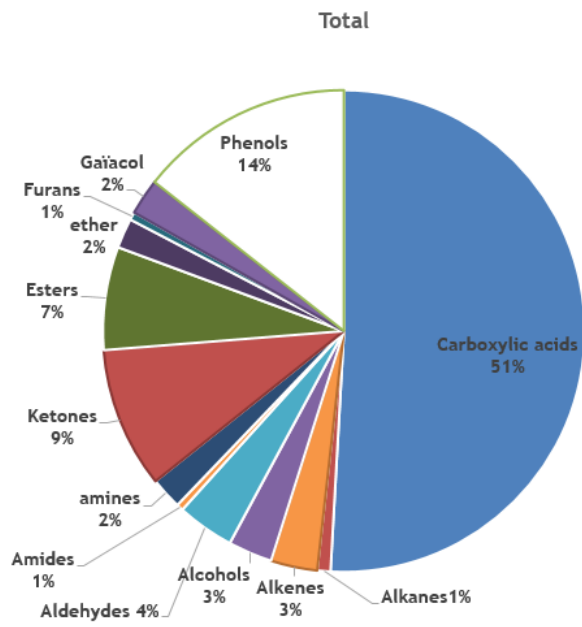

Figure A

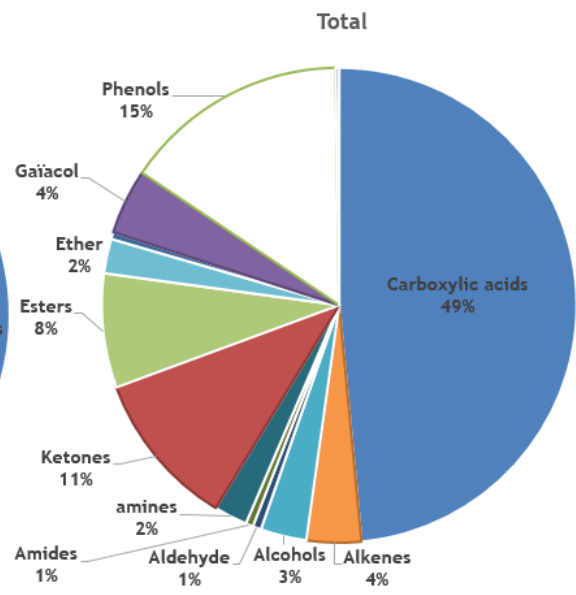

Figure B

Fig. 4. Chemical families in flax shives pyrolytic bio-oil

Both experiments have a similar average of absorbed power but different effective energies applied. from the percentages in table 7, it is clear that the distribution of chemical families is a little bit affected by the absorbed energy and temperature reached. The carboxylic acid production and therefore the oxygen rate are favored by an increasing absorbed energy where ketones formation is decreased. The percentage of phenols are stable in each case but the higher percentage of alkenes is found when lower energy is applied.

Table 7. Microwave pyrolytic bio-oil: effect of the effective applied energy

\begin{tabular}{|c|c|c|c|c|c|c|c|c|c|c|}
\hline $\begin{array}{c}\text { Mass of } \\
\text { biomass } \\
\text { (g) }\end{array}$ & $\begin{array}{c}\text { Average } \\
\text { absorbed } \\
\text { power } \\
\text { (W) }\end{array}$ & $\begin{array}{l}\text { Energy } \\
\text { applied } \\
\text { E (kJ) }\end{array}$ & $\begin{array}{c}\text { Maximum } \\
\text { temperature } \\
\left({ }^{\circ} \mathrm{C}\right)\end{array}$ & $\begin{array}{c}\text { Quantity of } \\
\text { compounds } \\
\text { detected by } \\
\text { GC-DID }\end{array}$ & $\begin{array}{c}\text { Oxygen } \\
\text { rate } \\
\%\end{array}$ & $\begin{array}{c}\text { Carboxylic } \\
\text { acids } \\
\%\end{array}$ & $\begin{array}{c}\text { Phenols } \\
\%\end{array}$ & $\begin{array}{c}\text { Ketones } \\
\%\end{array}$ & $\begin{array}{c}\text { Esters } \\
\%\end{array}$ & $\begin{array}{c}\text { Alkenes } \\
\%\end{array}$ \\
\hline 4.5 & 201 & 86 & 568 & 270 & 39.2 & 51 & 14 & 9 & 7 & 2 \\
\hline 4.5 & 198 & 67 & 640 & 272 & 37.8 & 49 & 15 & 11 & 7 & 3 \\
\hline 4.5 & 180 & 58 & 586 & 237 & 32.8 & 47 & 15 & 12 & 6 & 4 \\
\hline
\end{tabular}

\section{Conclusions}

The effect of the microwave heating using a rotatory kiln glass reactor for flax shives was investigated during the course of this study. The different steps of the pyrolysis reaction interfere in the stability of the microwave absorbed power and a precise tuning is required during the course of the pyrolysis. Microwave heating leads to high temperatures and heating rates and the rotary kiln reactor configuration favours homogeneity of the process.

When applying different incident powers resulting into different global applied energies, moderate differences on the products distribution were found. But, the higher the absorbed 
energy is, the higher bio-oil production is. In conclusion, the developed microwave pyrolysis process gives a clear way to produce an exploitable bio-oil from flax shives.

\section{References}

1. Abdelouahed, L., Leveneur, S., Vernieres-Hassimi, L., Balland, L., \& Taouk, B. Journal of Thermal Analysis and Calorimetry, 2017, Vol. 129, pp. 1201-12013

2. Beneroso, D., Monti, T., Kostas, E., \& Robinson, J2017, Chemical Engineering Journal, pp. 481- 498.

3. Bridgwater, A. Biomass Bioenergy, 2012, Vol. 38, pp. 68-94.

4. EIA (Energy Information Administration), Annual Energy Outlook 2010. 2010

5. https://www.europeanflax.com/. (2019, Juin 15) . Retrieved from Europuean Flax and Hemp.

6. Mohabeer, C., Abdelouahed, L., Marcotte, S., \& Taouk, B. J. Anal. Appl. Pyrolysis, 2017, Vol. 127, pp. 269-277.

7. Robinson, J., Dodds, C., Stavrinides, A., S. Kingman, Katrib, j., Wu, Z., Overend, R. Energy Fuels, 2015, Vol. 29, pp. 1701-1709.

8. Shiung Lam, S., \& Chase, H. A. Energies, 2012, Vol. 5, pp. 4209-4232 